\title{
Census-taking in Nigeria: The good, the technical, and the politics of numbers
}

\author{
Akinyinka Akinyoade', Eugenia Appiah ${ }^{2}$, \& Sola Asa $^{3}$ \\ ${ }^{1}$ African Studies Centre Leiden, Wassenaarseweg 52, Leiden 2333AK. \\ The Netherlands \\ a.akinyoade@asc.leidenuniv.nl \\ ${ }^{2}$ Research Department, Commission for Human Rights and Administrative Justice, \\ Accra, Ghana \\ euappiah@gmail.com \\ ${ }^{3}$ Department of Demography and Social Statistics, Obafemi Awolwo University, \\ Ile-Ife, Nigeria \\ solaasa2000@yahoo.com
}

\begin{abstract}
This paper examines the historical context of census-taking and its importance to development trajectory of Nigeria from 1866 to 2006 . Secondary data obtained from five-year national development plans, archival records, in-depth interviews and extant demographic literature were used to determine how population census exercises has evolved in a 140-year period, the problem of counting Nigerians living in Nigeria, and the politics of using population as a yardstick for distributing national wealth. The study shows that nearly all censuses were found to be grossly inadequate, tradition of conducting censuses every ten years has not taken root in Nigeria, and colonial administration as well as postindependence governments grappled with politics of numbers for socio-economic development planning. Despite flaws, the 1991 census remains relatively acceptable amidst fifteen complete and incomplete censuses ever taken in Nigeria in the period under study.
\end{abstract}

Key words: Census, Development, de Facto

\section{Introduction}

Sudden changes in trajectory of Nigeria's annual population size defy explanation. Available statistics indicate that Nigeria's population size rose steadily from about 40 million people in 1961 to over 100 million in 1988 when it abruptly dropped by almost 15 million in a space of two years in the absence of mass emigration, war, epidemics, or any other natural calamity that led to the disappearance of this massive number of Nigerians. And from 1999 to 200I, Nigeria miraculously gained over 10 million people (see figure I). With no apparent explanations for the sudden huge losses or gains in population size, one factor that emerges is the reliability of population data, obtained through censuses, surveys, and deployment of other statistical aggregation techniques. Either the data collected pre-1988 was bad, or the ones collected post-1988 are deficient.

One important source of demographic data in Nigeria since 1789 is population census. Nigerian
Censuses has been described as outcomes of tense political activities, and contributors to the debate often cite that census-taking in Nigeria has a history of political controversy and mutual ethnic mistrust (see Obono and Omoluabi, 2014; Diamond 1988). In this study, Nigeria's history of controversial censuses is deeply examined. Using population data obtained from national and international sources, colonial records, in-depth interviews, and review of extant literature spanning I40-year period (I866-2006) we chart the course of census-taking in Nigeria since late 19th century. Reliability of results of various censuses are assessed based on methods of population data collection, analysis, political interpretations, and ultimately the acceptability for planning purposes. Conclusions are made to highlight how successes can be built on and deficiencies avoided in the conduct of future censuses. 
Figure I: Trend of Nigeria's National Population 196I-2007

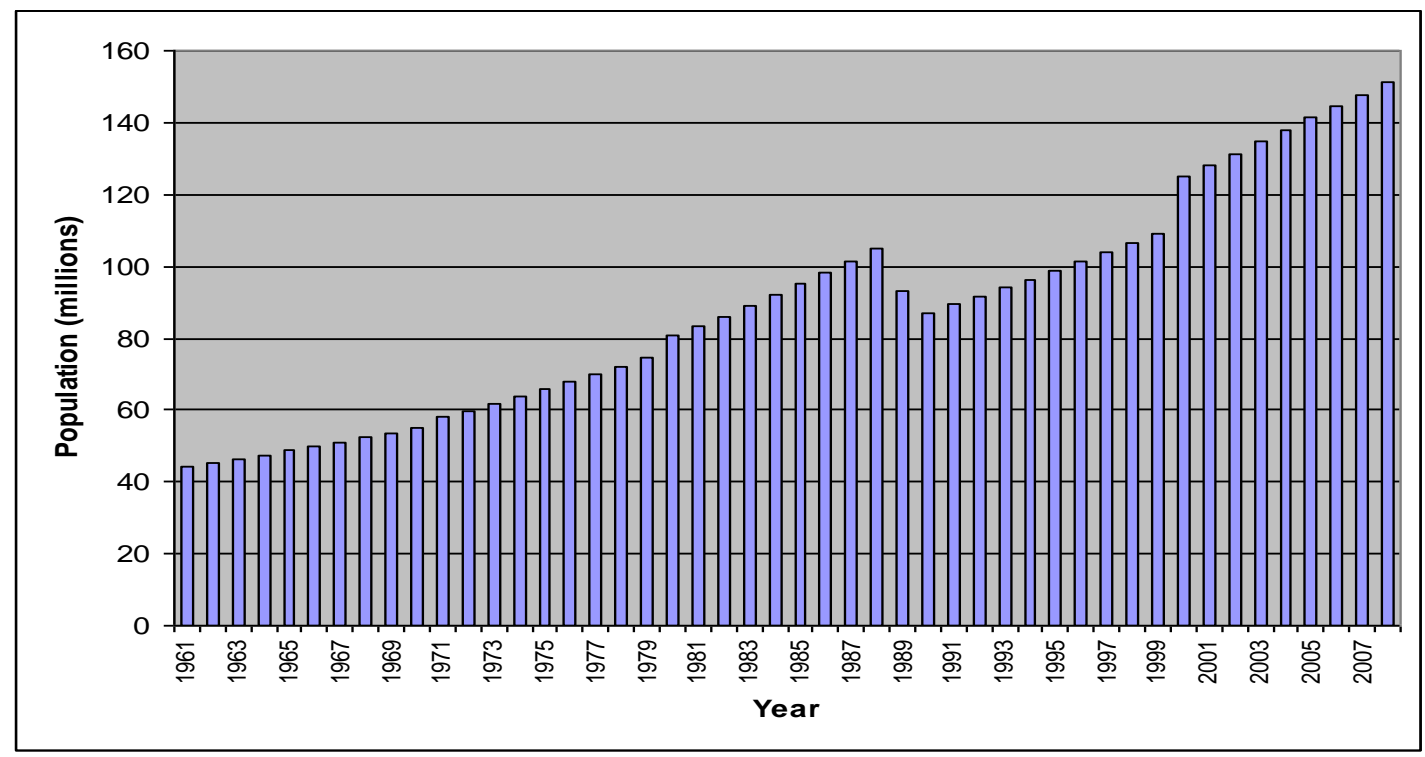

Source: Adapted from a combination of data from (i) World Bank - World Data Bank, World Development Indicators population projections for Nigeria; (ii) National Population Commission, I99I and 2006 Censuses and projections

Operationally, census is defined as the process of 'collecting, compiling and publishing demographic economic and social data pertaining, at the specified time to all persons in a country or delimited territory' (Shryock and Siegel, 1973: 15). In the prelude to a census exercise, six major activities are required which include: enumeration area demarcation (EAD); publicity; questionnaire design; selection and training of census personnel; pre-testing of questionnaires; and selecting appropriate method of data collection (Okolo, 1999).

Once the data is collected, population growth rate derived in-between censuses can be related to the economic growth rate, helpful for the prediction of job creation potentials, and other aspects of development planning. For instance, Dr Djunaedi Hadisumarto (personal interview, BAPPENAS Jakarta March 2010) gave an economic justification for reliable intercensal statistics to underline how crucial population statistics is to development planning: “...it has been officially estimated that an annual GDP growth rate that is one unit higher than annual population growth rate represents creation of 100000-200000 jobs per annum". Thus, population growth rate higher than GDP rate results in unemployment. According to Afolayan (1982), derivation of reliable relative rates of growth of the populations of the various components of a country is useful for development planning such as housing needs, estimating proportion of population of voting age, and revenue allocation for sub-national units; the latter being the bane to acceptability of census results in Nigeria.
But as simple as the population factor sounds, the bigger the complexity it has brought to governance and development planning of Nigeria. Nigeria's census experiences are so fascinating and instructive as nearly all census results have been classified as not true or unacceptable (Ahonsi, 1988). Census figures are immediately contested as soon as they are announced, not because they acutely departed from laid down preconditions of census-taking but because they generated ethnic wrangling on sharing of the national cake (Okolo, 1999; Bamgbose, 2009; Ahonsi, 1988; Morah, Adekunle and Adekunle, 198I). It appears that irrespective of systematic planning and execution, the ever-increasing public awareness of the political and financial implications of census results to sub-national units have made the typical post-independence census result controversial. The question remains, how can population factor be deemphasised in Nigeria's socio-political terrain given that the population factor has been entrenched in the nation's intergovernmental transfers (locally labelled 'revenue sharing formula') for decades. Such impression recurring for more than a century of different exercises serve as a justification to examining the history of population counts in precolonial, and post-colonial Nigeria.

This paper therefore describes factors that contributed more to the errors observed in the reported figures by unmasking turning points where errors and doubts were wittingly or unwittingly introduced, and how these cemented statistical discontent from one group to the other. Nigeria's census history since 1866 shows that fifteen partial 
and total attempts have been made, with varying degrees of success. We attempt to explain the conduct of successive censuses and how officials responsible sought to overcome immediate past and/or cumulative deficiencies with the aim of getting more accurate data in any upcoming census. The 1991 census is highlighted as a case study in this regard. In the end, it is observed that while no census can be perfect, there had been intense focus on errors and weaknesses raised by politicians and analysts of different persuasions, rather than strengths of the exercise. Government administrators and politicians who are responsible for using population figures for development planning are the first to reject it. An important question remains on what to do when the size of population that is to be planned for is unknown.

\section{Data sources}

In order to determine how population census exercises have evolved in Nigeria, secondary sources of information that captured records in pre-colonial times till 2006 are accessed. Primary information, which comprises interviews with officials of population planning agencies in Nigeria, Ghana and Indonesia are used to seek explanations to patterns that emerged from secondary data and processes that led to the emergence of such data. Population estimates are based on national population censuses. Mid-year estimates for the years before and after the census are interpolations or extrapolations based on demographic models developed by international agencies, collated under the World Development Indicators (WDI) available online at The World Bank. Thus, Nigeria's population figures were obtained from a series of sources such as: Nigeria's National Population Commission (199I and 2006 censuses); estimated and projected values for the period 1960 1990 (See World Bank reference). The WDI data was resorted to due to unavailability of reliable population data generated by Nigeria in the period 1960-1990 (this is discussed in detail in subsequent subsections).

The population estimates were supplemented with secondary qualitative information obtained from Nigeria's National Development Plan (1962-1968), Second National Development Plan (1970-74), Nigeria's Third National Development Plan (19751980), Military Decree 23 of 1989. These documents were not appraised in their entirety, but relevant sections were consulted for government's position on the population question. In addition, census exercises that yielded population counts in the pre-colonial and colonial times were sourced from publications of Aluko (1965), Makinwa (1985), Olusanya (1989), Okolo (1999), and Bamgbose (2009). Other extant demographic literature that provided insights as to processes and use of population counts have been duly cited.

Table I below shows a summary of censuses ever conducted in Nigeria in respective contexts of governance and results.

Table 1: Summary of results of Nigeria's population censuses 1789-2006

\begin{tabular}{llll}
\hline No. & Governance context & Year & Result \\
\hline 1 & Pre-colonial (Lagos) & 1789 & 5.000 \\
2 & Pre-colonial (Lagos) & 1815 & 11.000 \\
3 & Pre-colonial (Lagos) & 1855 & 20.000 \\
4 & Pre-colonial (Lagos) & 1861 & 30.000 \\
5 & Colonial (Lagos) & 1871 & 29.000 \\
6 & Colonial (Lagos) & 1881 & 37.000 \\
7 & Colonial (Lagos) & 1891 & 33.000 \\
8 & Colonial (Lagos) & 1901 & 42.000 \\
9 & Colonial (Southern \& Northern Nigeria) & 1911 & 16.060 .000 \\
10 & Colonial (Southern \& Northern Protectorates) & 1921 & 18.720 .000 \\
11 & Colonial (Southern \& Northern Protectorates) & 1931 & 20.060 .000 \\
12 & Colonial (Southern \& Northern Protectorates) & $1950-53$ & 30.420 .000 \\
13 & Nigeria (independent) & $1962-63$ & 55.660 .000 \\
14 & Nigeria (independent) & 1973 & 79.800 .000 \\
15 & Nigeria (independent) & 1991 & 88.500 .000 \\
16 & Nigeria (independent) & 2006 & 140.003 .542 \\
\hline
\end{tabular}

Source: Adapted from a variety of secondary materials described in subsection on Data

Results: Populations counts in pre-colonial, The early days of census-taking in Nigeria colonial and independent times
The first known population figure recorded in Nigeria is traced to documents of one Captain Adams an 
American sailor who estimated population of Lagos to be 5000 in 1789 (Aluko, 1965). More estimates were to follow in I8I5 (I I000), in I855 (20000), and in |86| (30000) for British-occupied Lagos. The technical basis on which these figures were obtained remain unknown, and there is a contention as to when the first real population count or census took place. Makinwa (1985) asserted that the first real census took place in 1866 and covered only the Lagos area, but Aluko (1965) noted that despite the I863 census ordnance that compelled the 1866 exercise, figures for 1866 and 1868 remained mere estimates and that the first real count was in 187I which yielded 29000 ( 1000 less than that of 1861 ). In this paper, $|87|$ is used as base date for censustaking in Nigeria as many scholars converged that from this point the British tradition of taking censuses in year ending with figure ' $l$ ' at decade interval was adopted. Available records showed Lagos population fluctuated in the early stages: 37000 in 1881,33000 in 1891, and 42000 in 1901.

Following a recommendation of the Selbourne Committee (1898) that was appointed to consider the future administration of Nigeria, the Lagos colony was merged with other communities in Southern Nigeria to create the Southern protectorate in 1906 (Okafor 198I; Ballard 197I). This led to the spread of census-taking to the whole of what was then known as Southern Nigeria in 1911. But the exercise was partial in that house-to-house count only took place in II main ports of the south (including Calabar, Bonny, Opobo, Degewa and Brass). Beyond the ports, hinterland, population estimates were derived for the rest of the southern provinces. For the Northern Protectorate, Aluko (1965) and Bamgbose (2009) maintained that census-taking followed the simplest ever imagined procedure at the government house in Zungeru where a figure was guessed and promptly written on a sheet of paper.

Amalgamation of the Southern and Northern protectorates into the federation of Nigeria by Lord Lugard in 1914 provided impetus for a national census in 1921. This made population enumeration to become much wider in scope,

more elaborate and first in the series of systematic attempt at nationwide decennial census (Olusanya, 1989a). The 1921 census covered the whole of Nigeria in two ways: township census conducted on 24 April 192I covering I3 townships; and provincial census spread over a two-month period from March to May 1921 (Okolo, 1999). A relatively high degree of accuracy was accorded the townships census (given a 5\% margin of error); data collected in the provincial and rural areas was given a larger margin of error due to vigorous dislike many tribes showed to enumeration, and shortage of European staff, an aftermath of World War I. Thus the overall result was compensated for by additional $5 \%$ of figure to townships and 10\% to other areas (Aluko, 1965). Without this compensation, Nigeria's population stood at 18.36 million (South 8,37I,000, North $9,998,000$ ); with adjustments the figure rose to 18.72 million people (Okolo 1999; Aluko 1965).

In 1931, another attempt was made to enumerate the whole country; actual counting of persons took place only in Lagos and five other townships, in 20I villages in Northern Nigeria, and for all foreign population in the country at the time. The exercise was hampered by the world-wide economic depression that began in the late 1920s, and locust invasion in many areas of Northern Nigeria. Also, three years earlier, a poll-tax introduced in the Eastern provinces led to rioting in Aba, Onitsha, Owerri and Calabar for fear that it might be extended to women. In the riot-affected areas, population estimates were derived from existing tax returns and records (Okolo, 1999), which justified latter day reluctance by the Southeast for subsequent census exercises organized by the colonial administration.

In 1931, the population of the Southern and Northern Provinces were given as $8,493,000$ and I I,435,000 respectively. Looking at the total figure, it appears that there was little growth in population between 1921 and 1931. The Government Statistician summed up his assessment that census figures are slightly defective (5\% underestimation) in the Northern Provinces and much in defect (up to $20 \%$ underestimation) in the Southern Provinces, thereby confirming an impression that the 1931 census was a gross under-estimate for Southern Nigeria (Aluko, 1965; Orubuloye, 1989).

The occurrence of World War II (WW II) led to the skipping of 194I census in Nigeria and by 1946, MacLeod-Smith observed that:

"No very prolonged study of existing Nigerian statistics is required to show that they are entirely inadequate for the purpose of large scale development planning. We do not even know what the population of the country is...The complete lack of adequate statistics outside Lagos meant that no one has any idea of the rate of increase of the population of Nigeria, though there may be unmistakable signs that it is increasing (Macleod-Smith 1946)"

\section{0-53}

In the backdrop of Macleod-Smith's comments, another census was conducted in a staggered format from 1950 to 1953. The first exercise took place in Lagos in 1950 and 195I to test the suitability of new 
census methods; followed by another exercise in the North in May-July 1952; West and Mid-West in December 1952-January 1953, and in the East - May, June, and August 1953 (Okolo, 1999; Olusanya, 1989b; Barbour and Prothero, 196I). This staggering was necessary to enable the Department of Statistics to handle and tabulate the great quantity of data. The census was an improvement on previous censuses given its coverage of the country, but again lacked in data comparability due to different timing of the exercise in Nigeria's constituent regions. The recorded total of 30.42 million was distributed as 16.84 million Northern Nigeria and the remaining proportion divided between the Eastern and Western parts (both comprising the larger South).

Also, the exercise and results of the 1950-1953 census suffered from doubts and suspicions that affected pre-WW II counts. From a technical perspective, Okonjo (1968) estimated 18\% undercounting across the country. In Northern Nigeria, many villages were omitted due to difficult terrain which taxed already inadequate transportation modes (Duru, 1968); the mostly Islamic region opposed the counting of women in purdah. In the South, many others did not permit enumeration of their wives and children (proxy measure of a man's wealth, army enlistment and a reference point for tax collectors to demand heavier taxes); and superstition that census brought ill-luck, famine, or misfortune to those that participated in the pre-WW II counts.

The figures were contested mainly by Southern Nigerian politicians, particularly when the figures were used for the proportional allocation of regional seats in preparation for elections into the Federal Parliament, as colonial Nigeria's three regions got set for higher degree of self-government. From the figures, the North was allocated 174 seats, East 73 seats, West 62, and Lagos 3 seats in the House of Representatives. Usage of the census result this way marked a turning point in the realization of potential political power to accrue from the number of elected members to Parliament or local councils.

\section{2}

The quest to know 'how many Nigerians' continued immediately after Nigeria attained independence in 1960. By 196I, a Federal Census Office, ran by the Federal Chief Census Officer, was created in Lagos. For the three administrative regions of Nigeria, each Regional Ministry of Economic Planning had its own census office, headed by a Regional Census Officer (as Chief Statistician or Senior Statistician of the Region).

The first post-independence simultaneous country-wide census was slated for May 5 to May 21, 1962. Indeed, counting began on May 5. De Facto (count on sight) method of enumeration was adopted. Some persons such as nomads, shopkeepers, street children who do not live in recognizable residential houses posed problems for census organizers. Also in Nigeria at this time, less than $15 \%$ of the population was literate and less than $1 \%$ kept birthday records (Aluko, 1965). Age data had earlier been haphazardly collected in the 1950-53 census, which had negative effect on the take-off of free education programme of Western Nigeria introduced in January 1955. In the build-up to launching of the programme, 170,000 children were expected to reach the ages of six and seven in 1955. Upon completion of registration in December 1954, 392,000 children of school going age were discovered, $230 \%$ more than planned for (Fafunwa, 1974), signposting statistical defect of the 1952-53 census on which the estimates were based. Smarting from this experience that arose from incomplete individual data, the Western Regional administration insisted that the Census Office in Western Nigeria give more attention proper collection of age data in planning for the 1962 census.

\section{2-63: Controversies in the house}

Inaccuracy of the 1962 census data mimicked the 1931 experience as it was generally affected by shortage of qualified personnel to undertake the actual count, shortage of funds, problems with communication, such as in the riverine areas, and previous suspicions associated with what census result might be used for.. This was worsened by politicians and government functionaries that put great weight on relevance of census for allocation of government amenities and the number of parliamentary seats, ostensibly turning the census exercise into a political rather than a statistical affair, which in the long run rendered results unacceptable to the three regional governments that constituted the Nigerian federation (Okolo 1999).

Disturbing political influences and lingering suspicions led to the eventual rejection of the 1962 census figures. Prior to releasing the census results, the Federal Census Officer contended that the figures recorded throughout the greater part of Eastern Nigeria during the census were false and inflated.

But allegations came against the North as it emerged that as at November 1962, enumeration was on-going for an exercise that ought to have ended six months earlier. Evidence of double counting was worsened by delayed release of the census figures, leading to rumours of in-office inflation. Representatives of different political persuasions staged a walkout of federal parliament in protest as the Chief Federal Census officer again read 
his adverse report on 5 December 1962 (Aluko, 1965).

\section{3-64: Census re-taken}

With the Prime Minister's repudiation of the 1962 census result in February 1963 (Daily Times Editorial, 20th February 1963), a new census was proposed for later in 1963, and the responsibility for planning and conduct was removed from regional governments. The federal government set up a central census board that was chaired by the Prime Minister. New steps taken were to allocate a larger sum of $£ 2.5$ million (up from $E \mathrm{I} .5 \mathrm{~m}$ of 1962) to accommodate the hiring of more enumerators and inspectors, and the enumeration period limited to 4 days - November 58, 1963 (down from 17 days of 1962), to reduce the probability of multiple counting. Within three months, in February 1964, provisional census figures gave Nigeria's population as 55.7 million. The regional distribution of figures was challenged at the Federal Supreme Court by the Eastern Government in 1964 (Aluko, 1965).

\section{3: After the civil war}

Another census exercise was undertaken in 1973. Now under military rule, with no national elections in sight, and with Nigeria's attention on reconciliation and reconstruction after the civil war of 1967-70, there was simply no reason to fear deliberate inflation of results of this particular census exercise. The National Census Board conducted this census from November 25 to December 2, 1973. Preparatory work to reduce or avoid pitfalls encountered in the 1962-1963 census was carried out with the aim of ensuring acceptable figures to the federal and state governments. Specialised counting was done for unique groups (Bamgbose, 2009).

But the newly released results of 79.8 million total population of Nigeria still confounded regional belief. To the consternation of Southern elites, $64 \%$ of this total belonged to the six northern states. The corollary was that Southern states were either declining or growing ever so slowly; bitter accusation of deliberate inflation was again leveled against the North. Chief Awolowo was the first national politician who labelled the 1973 figures as unreliable and publicly rejected it. General Murtala Muhammed who deposed General Gowon in 1975 did not permit the use of the 1973 population census. A government report published in November 1975 (Federal Republic of Nigeria 1975) rejected the results, and recommended that the 1963 census figures should continue to be used as basis for development planning.

By the mid- and late 1970s, international financial and development organizations had got sucked into
Nigeria's demographic debacle in their dealings as they bandied and used different population growth rates, which yielded different population sizes. These different growth rates also helped to account for inconsistencies observed in the trajectory of annual population figures of Nigeria. Population pressure led to inadequate and collapse of public infrastructure by the mid-1980s. A half-hearted attempt made at implementing a population policy stuttered to a stop by 1990 .

\section{1}

Despite the nation's chequered history at taking censuses, the Political Bureau set up by the Federal Government of Nigeria advised in 1987 of the need to conduct a reliable and acceptable population census. The decision was given legal support in Decree 23 of 1989 promulgated by the Babangida-led administration. It was based on this decree that National Population Commission (NPC) was empowered to conduct population censuses in Nigeria, among other duties. The technical and administrative arm of the new NPC comprised functionaries that had academically assessed previous censuses (see Duru, Morah, Adekunle and others). This group immediately embarked on Enumeration Area Demarcation (EAD) exercise on local government (LG) basis, to divide LG into units with clear physical boundaries containing 450-600 persons, and complete house listing (residential, nonresidential, uncompleted building) of each EA. In the absence of topographical maps and costly aerial photographs, cartographers were employed to sketch maps from field visits obtained from each EA to have comprehensive road and building location maps for Nigeria (recount by corresponding author of experience as EAD Field Officer in Oyo, Ogun, and Akwa lbom States).

Following nationwide EAD, three pre-tests and one trial census were conducted in the run-up to 199| census. The commission also launched a public enlightenment program for the 1991 census in May 1990 to explain the processes, including the preparations and the technical efficiency of the program and assure Nigerians of the thoroughness of the preparations. What further engendered public confidence in pre-census activities was the music album voluntarily released by 'General' Kolington Ayinla to dispel superstitions associated with headcounts and urged active local participation; he commanded large following of Fuji music in the Southwest.

Highly educated manpower were employed and trained. Teacher Training certificate and Bachelor degree was the minimum qualification expected of enumerators and supervisors respectively; de Facto 
method was adopted for the counting exercise which started on November 27, 1991. Special enumeration was done for 'homeless persons' midnight preceding the census. Enumeration at residences ended on November 29 in a nationwide atmosphere where there was strict non-movement of persons except for census officials. Provisional total which put the country's population at 88.5 million was released by government on March 19, 1992, four months after the census. This figure indicated a $23 \%$ deviation from the estimate of about II5 million population projected from the 1963 census. The 1991 census total show that Nigeria's population grew at an average annual rate of $2.1 \%$, far below the high $3.2 \%$ that had hitherto been used by many international organizations such as the United Nations and the World Bank. The new growth rate seem more like those reported for other countries in the West African region (Okolo, 1999).

With the experience that results of Nigerian censuses had always been contested, the Babangida government pre-empted potential local and regional discontentment with census results by setting up arbitration tribunals, which began their functions before the census exercise in areas where administrative boundary disputes existed.

\section{6}

The tradition of conducting census in years ending with ' $I$ ' could not be maintained as census 2001 was postponed for various reasons until 2006 (for example, census exercise should not be held close to period of 2003 national elections, so as to forestall political influence). The 2006 head count was held from March 2I to March 25. In the usual pre-census tradition, the NPC incorporated more contemporary technical applications to plan and conduct the 2006 census. The latest technique at this time was the use of Geographic Information System (GIS), Geographical Positioning System (GPS) and Satellite imageries to delineate out geo-referenced Enumeration Area maps, Optical Mark Recognition (OMR), Optical Character Recognition (OCR) and Intelligent Character Recognition (ICR) machine readable forms to record information, Automated Fingerprint Identification System (AFIS) were deployed to detect where same finger prints have been used to falsify questionnaires and thereby expose cases of multiple counting (Obasanjo, 2006).

On January 9, 2007, President Obasanjo released Nigeria's provisional population of March 2006 as $140,003,542$. Discontentment immediately followed with commentaries in national dailies such as: ' ...It is tinted with political permutations' (Onyeka-Ben, 2007), 'Delay in release gave room for manipulation' (Adim, 2007), 'Census 2006: matters arising'
(Akerele, 2007) and captions: 'Lagos and the fallacies in national census figures' (Kolapo and Faloseyi, 2007). Let us consider one of the examples of main bone of contention: disparity in the census results of Lagos $(9,013,634)$ and Kano State $(9,383,682)$. In defence of how wrong the data of Lagos was, critics argued that the World Health Organization (WHO) earlier used the result of the numbers of children it immunized in the state from year 2000 to 2006 to project a total population of about 16 million for Lagos state. In addition, if we are to base population estimate on the 26000 EA of Lagos, with average population of 750 (per EA), there will be 19.5 million people residing in Lagos state (also see Kolapo et al., 2007). Lagos state authorities therefore conducted an 'independent' statewide census and arrived at $17,552,942$. The state governor suggested:

"We can afford a recount throughout the country. We want a recount in Lagos State. This is the height of corruption: falsifying census figures just to please some people. No amount of adjustment done to the figure can make it right. The figure is totally rejected. We have enough support and funding from the United Nations and the European Union. So let's have a recount (Tinubu, 2007)".

In addition, arguments against the figures released for Kano State (and the Northern states in general) hinged on a litany of cycle of violence that generated thousands of internally displaced persons and claimed many lives since the 1990s. They include mayhem in: Bauchi state 199I; Junkun and Tiv conflicts in Taraba state 199I and 200I; Chamba-Kuteb crisis, Taraba state 2000; Damboa religious crisis, Borno state 2000; communal clashes, Nasarawa state 200I; Bongoro crisis, Bauchi state 200 I; Plateau state 200I and 2004; Kano riots 200I; crisis of all sorts in Kaduna state 1992, 2000, and 2002; inter-ethnic clashes Adamawa state 2003; chaos of different sorts in Kano state 1991, 1999, 200I, and 2004; the Kwande, Benue state political crisis in 2004. Bamgbose (2009) concluded that crises at such level of annual occurrence should have decimated the northern population in proportions similar to, and if not more than millions of death the East suffered during the 1967-70 civil war. Added to this was the perceived migration of people from the north to the south in search of greener pastures, literarily, which ought to have reduced the number of people in the north and increased the number of people in the south.

However, an official of the NPC, under the condition of anonymity, stated that the 2006 suffered mostly from ill-preparation; "preparatory EAD 
exercise was sorely lacking prior to the 2006 census, which saw sizeable areas of Lagos State not enumerated on census day, and eventual claims of undercount. The strength of the 1991 census was in the 3-year preparatory EAD exercise" (NPC official, Ibadan, December 20I5).

\section{Discussion}

Examination of thirteen censuses that pre-dated I99| national census shows two main sources of problems; first is technical (such as incompleteness of data) and secondly, cyclical discontent and disagreements particularly among political and administrative leaders. The latter stems from the processes of census exercise and the use of figures that emerged from such counts.

The foundation of technical deficiencies was laid in the crude process of estimating population count for the Protectorate of Northern Nigeria in Zungeru 1911 , in a census exercise that did not take place (Aluko, 1965). Also, if we consider the disruption in the planning and execution of the 1921 and 1931 census exercises, occasioned by administrative difficulties, lack of money, and the scarcity of qualified personnel, grounds for population underestimation especially of the south (combination of east and west) had been prepared (Okolo, 1999). Particularly for Lagos, Mr. H.N. Thompson, officer in charge of the 1931 census submitted that:

"There is no doubt that the entire Lagos census has been more or less inaccurate, and the reasons for this are not far to seek. Census taking depends for its success above all, on the willing cooperation of the people counted, and that cooperation is extremely difficult to obtain in Lagos (See Bamgbose, 2009)".

One can conclude that between 1866 and 193I, censuses did not meet all the required characteristics (individual enumeration, universality, simultaneity, and defined periodicity) as actual enumeration were conducted only in a few places due to reasons cited earlier. The years 1911 and 1931 thus became reference points for the contestation of larger population estimates for the North, and arguments for or against figures on population distribution of Nigeria in subsequent exercises. Latter day censuses have also not been spared of technical deficiencies the continuous 1962-63 exercise way beyond the stipulated dates in the north, which paved way for unrepentant multiple counting. And the 2006 results was tainted by inadequate EAD preparation; accuracy of internal distribution remains disputed; logistic 'shortages' of census materials were seen as deliberate ploy to inflate census figures in some areas
(Obono and Omoluabi 20I4). Census officials have not been left off the hook; Ebigbola (198I) asserted that while Nigeria can now boast of a large number of capable technical staff that can handle enumeration effectively, these staff have equally become torn in the flesh of population census in Nigeria, for they have been responsible for falsification of population figures. According to Obono and Omoluabi (20I4), strong and institutional controls for credible censuses were often subverted by exigencies encountered by census functionaries in the field and this might have undermined data quality.

The second category of problems is political in nature. The 1962 and 1973 counts were dropped due to the intense political tensions they provoked, and though the 1963 result was initially officially accepted, subsequent widespread dispute led to it being dropped.

The effects of these two categories are felt in many dimensions. Take for instance, intercensal growth rates. The count of 1963, implied a $44 \%$ increase in Nigeria's population over that of 1950-53; by the 1973 census, the population was supposed to have risen by about a further $30 \%$ over that of 1963 . Many scholars viewed such massive increases as unrealistic and indicative of deliberate inflation of figures, indicative of political and technical problems. Udo (1968) blamed the excessiveness of 1952-63 intercensal growth rate on politicians' desire to secure more electoral seats; regional governments made sure that their 1963 figures of their regions or constituencies were "larger than those for 1962 in order not to appear guilty of inflation in the nullified census of 1962' (Yesufu, in Ahonsi 1988). The retaken census of 1963 that yielded $57.7 \%$ proportion in favour of the North (up from previous 49.2\%), was deemed political rather than technical increase. However, Ogunlesi (1968) contends that these disparities, though abnormal at first sight, may have been due more to the serious operational problems encountered and gross inefficiency on the part of many fieldworkers than to conscious manipulation. Constant bickering over true population size of constituent sub-national units of Nigeria has implications for accuracy and acceptability of future censuses to different segment of the country. This allows us to examine other non-political factors that contributed to problematic census-taking in Nigeria.

For the north, the rationale for the count inflation charge against Northern Nigeria stems from observation of excessive intercensal growth rates of the population, in a region typified by semi-aridity and low population density. In some instances, doublecounting may have arisen from the 'Nigerian habit of belonging simultaneously to a place of work different from place of birth/origin', an observation earlier 
made by (Aluko, 1965), yet still very much in operation today. Also, distortion in figures of the 1962 and 1973 censuses was due to discovery of new settlements not listed in a previous census. Some of these settlements were labeled fake by Southerners. Also, health developments resulted in declining mortality and increasing fertility in the relatively poorer regions of the North in the early 1970s.

On part of the South, smaller census results in the 1950s and 60s may not be disconnected from the large swathe of Southern Cameroons that left Nigeria to join Cameroon following a plebiscite. People in this area had been counted as part of colonial southern Nigeria in the 1953 census. Despite reservations displayed by Eastern Regional Government against the results of the census retaken in 1963, the AG-led Western Regional Government quickly publicly accepted the outcome despite lower returns for the West. Whether the AG leader identified non-political reasons for changes in intercensal population, is left to conjecture. In addition, in the 1960s, over $75 \%$ of Nigeria's population lived in the rural areas; a large proportion of this group viewed the census as a means of tracking down tax payers, which they tried to evade. This spurs another question: did the higher figures returned for the North indicate that Northerners were open to taxation compared to Southerners?

For the 1973 census, drop in the number of people in the Eastern states is traceable to the impact of 1967-70 civil war that decimated the population. Many children died at this time, with implications for population replacement. The drop in numbers in some areas of the West could be linked to the growth of Lagos, Nigeria's premier city in the early years of the oil boom. Lagos grew as Nigeria's industrial and commercial nerve centre, it attracted population of bordering States in droves.

With the background of controversies, questions arise: who modified the figures to the advantage of the North? How did this occur: why did citizens avail themselves for multiple counting as alleged? Were enumerators instructed to fill census questionnaire to the brim with fabricated information? Did central level politicians simply scribbled figures as was done in $|9| 1$ ?

Ironically, government's official stance in the first three Development Plans did not see population growth as a problem, in that:

"The basic objective of planning in Nigeria is not merely to accelerate the rate of economic growth and the rate at which the level of the population can be raised" (National Development Plan 19628) "given the promising resource base of the economy, the country can through careful planning, succeed in buying time to ward off undue population pressure" (Second National Development Plan 1970-1974, Section 5 of chapter 8, p.77)

"Although Nigeria has (by world standard) a large and rapidly growing population, these demographic factors do not appear as yet to constitute a significant or serious obstacle to domestic economic progress" (Third National Development Plan, 1975-80, p.293).

This official stance raises the question of the basis on quality of data used for planning purposes. If federal government that controls the purse-strings of Nigeria's wealth does not know the size of population it is planning to deliver social services to, and it is not bothered by lack of accurate knowledge of age structure and composition (regional characteristics) of the population it governs, then there is a fundamental problem for effective planning and delivery of social services and formulation of policies to stimulate economic growth. Incomplete figures has implications for national economy accounting. Specifically, defective intercensal rates of growth has negative implications on estimations of the nation's Gross Domestic Product (GDP) per capita, which Dr. Hadisumarto of Indonesia's planning bureau (BAPPENAS) aforementioned. As was aptly forewarned by Aluko (1965), "the end-result of all these economic implications is that though Nigeria's political stature in the world may have been enhanced by the higher population, its economic stature has been considerably reduced."

\section{Indonesia and Nigeria}

Indonesia provides hints on how Nigeria may escape problematic censuses. But why compare Nigeria with Indonesia? The two countries are superficially similar. Both are huge, populous (Indonesia has about 250 million people; Nigeria nearly 200 million Population Reference Bureau 2016), and ethnically diverse. Both countries experienced military rule particularly 1966-1999, and, at times, terrible violence. At independence, in 1945 and 1960 respectively, both Indonesia and Nigeria were extremely poor; with subsistence farmers in majority occupation. But then both struck oil, and after the sudden quadrupling of the oil price in 1973-74 both were deluged with floods of petrodollars (The Economist, 2000). Their first military coups were launched within months of each other - in September 1965 in Indonesia and in January 1966 in Nigeria - and their military regimes died within 12 months, in May 
1998 and 1999. In those years, while Indonesia's economic trajectory improved, Nigeria's economic fortunes declined, measured in GDP per capita.

On the track to economic success, one policy that Indonesia took ingenious ways to implement was its national population policy. The main aim was to achieve reduction in family sizes, specifically to two children per woman towards stimulating socioeconomic development (Akinyoade 2013). One method of encouraging couples to adopting family planning methods to stay within this family size limit was the introduction of public housing, first in Jakarta, where couples with maximum of two children had direct access to residential apartments allocated in a government program. Those who exceed family size limit are evicted, and had to look for other housing which turned out to be more expensive. Dependency burden at the family level declined. Secondly, derivation percentage is at the advantage of Indonesia's producing regions, and population had lesser weight in intergovernmental transfers. Subnational units thus found it easier for development decisions to be taken locally and ensure local productivity. In combination with huge investments in education, small family sizes and increased productivity boosted Indonesia's GDP per capita (Akinyoade, 20/3). An unintended consequence was that the incentive to alter census figures was removed.

\section{Conclusion and recommendations}

Lessons on better ways of overcoming political and technical problems associated with census results are taken from Indonesia. The processes may in the first instance appear tangential to census taking, but in the end eradicates most of the technical and political problems.

Analysts from Aluko (1965) to Obono and Omoluabi (2014) have focused their recommendations largely on the technical aspects of census-taking in Nigeria. Their recommendations are sound but this study takes another approach - the socio-political connection. The incentive to overestimate or inflate census figures will remain if there is no attempt at downscaling the importance of population factor in intergovernmental transfers. This has been worsened by the unrepentant focus on distribution of national proceeds (VAT, and oil and gas revenues) instead of enhancement of production. To achieve the downscaling, there needs to be an intensive lobbying of the Senate Committee on Population and National Identity Committee to introduce into Nigeria's constitution a phased downscaling of the weight that population factor carries in intergovernmental transfers. A concomitant effort should be to increase the percentage accruing to regions by derivation of revenue in the same period, back to the level enjoyed by three main regions prior to 1960. In this way, the undue attention given to population size is gradually withdrawn, and incentive to overestimate or superinflate census figures will be minimized. While this may seem far-fetched, optimism for success can be derived from the length of time it has taken democratic governance to take root and stabilize in Nigeria to the extent that power shift now popularly takes place on basis of elections irrespective of religious and ethnic leanings (re: 20II and 2015 national elections). A case is made for de-emphasizing population factor in Nigeria's intergovernmental transfers in ways that was done in Indonesia. Therefore, there needs to be an emphasis shift from distribution (sharing of national cake) to production (necessity to bake it before it is shared).

On the technical side, it also calls for a rethink of the vital registration programmes of the NPC. On paper it incorporates both active and passive method of data collection, but inadequate attention to staff motivation (reduced training programmes, delayed salaries) have caused serious deficiencies in collection of vital registration data. Where EAD is complete and active vital registration system is in place, such records would not only serve as effective checks on census results but also help in management of public service delivery programmes. Thus, there is the need to adopt more pro-active system for collecting vital statistics (events like births, deaths, migration, marriage, divorce) to update inter-census data.

Over the years, census taking in Nigeria evolved from sailor's impressions of population size, colonial officials' estimating numbers of people on a piece of paper in an office, to systematic collection of data using questionnaires, expanding the scope and completeness of data, discarding sensitive questions and adopting GIS. But the question, "How many Nigerians?' still remains controversial. Ethno-regional sentiment - the fear of any group of elites that the higher figures would be deliberately returned for another ethnic group or political zone to justify reception of a bigger portion of the national cake - is used to exaggerate perception of distortions in returned figures.

While the adoption of technological advancement is hailed, these should be seen as tools towards an end; adequate preparatory EAD work and consistent vital registration system to update intercensal data are crucial.

Linked to the preparation are legal and financial issues. While years ending in ' $I$ ' at decennial intervals appear to be the accepted years for censuses, apparently it is not based on any legal or constitutional provision. This makes it easy for 
government to balk at making financial outlays for EAD preparatory to a census at the requisite interval. Quite recently, the Chairman of the National Population Commission, Eze Duruiheoma, reported to Nigeria's Senate Committee on Population and National Identity Committee on Oversight that it "... has not been part of legislation, [and it is not] embedded in our constitution as to say after 10 years, there will be a census...".

From independence to 2006, motivations for over-count in Censuses existed in form of political representation and revenue allocation at the national level. The importance of population in the revenue allocation formula for states and local government councils has to be re-appraised. For more promising intergovernmental transfers, census figures may have been inflated in the past by nearly all segments of the country. It is recommended that emphasis in the distribution of revenue should be shifted from a large population size to specific economic and social programs aimed at improving the quality of life of the people concerned. It is only when further advancement in Nigeria's system of public service delivery and de-emphasis of population figures in Nigeria's revenue allocation system, then census figures may start becoming acceptable in Nigeria.

All named authors have contributed sufficiently to the work submitted and the content of this manuscript has never been previously published.

\section{References}

Adim, F. 2007, January 12, "Delay in release gave room for manipulation. Lagos, Nigeria." The Guardian, 27. In, Bamgbose, B. J 2009, "Falsification of population census data in a heterogeneous Nigerian state: The fourth republic example." African Journal of Political Science and International Relations, 3,(8): 3 I I-3 I9.

Afolayan, A. A (1982): Population. In A. L. Mabogunje ed., Geographical Perspective on Nigerian Development. Ibadan, Nigeria: Heinemann Publications.

Ahonsi, B. A 1988, "Deliberate falsification and census data in Nigeria." African Affairs, 87, (349): pp 553-562.

Akerele, T 2007, January 15, "Matters arising." Lagos, Nigeria: The Guardian, p.65

Akinyoade, A 2013, 'Population Programmes and Their Implications for Poverty Reduction in Indonesia and Nigeria, 1966-1999'; in, Bernard Berendsen, Ton Dietz, Henk Schulte Nordholt \& Roel van der Veen (eds) Asian Tigers, African Lions. Comparing the Development Performance of Southeast Asia and Africa. Leiden: Brill. Pp. 175196.

Akinyoade A. and Enweremadu D. 2015. "A Tale of Two Giants: Oil and Economic Development in Nigeria and Indonesia (1960-1999)" Global Development Studies, 7, (3-4): I6I- 195

Aluko, S.A 1965. "How Many Nigerians? An Analysis of Nigeria's Census Problems, 1901-63." The Journal of Modern African Studies, 2, 37I-392.

Ballard, J.A 197I. "Administrative origins of Nigerian Federalism.” African Affairs 70, (279): 333-348.

Bamgbose, B. J 2009. "Falsification of population census data in a heterogeneous Nigerian state: The fourth republic example." African Journal of Political Science and International Relations 3, (8): 3||-3|9.

Barbour, K. M. and Prothero, R. M (eds.) 196I. Essays on African Population. London.

Diamond, L. J (1998). Class, ethnicity and Democracy in Nigeria: the failure of the First Republic. Syracuse University Press, Syracuse, New York I3244-5260

Duru, R. C 1968. "Problems of Data Collection for Population Studies in Western Nigeria." In, J.C. Caldwell and C. Okonjo (eds.) The Population of tropical Africa. London: Longmans, pp. 7I-72.

Iro, "Post-Independence Population Census Data in Nigeria”, p. 14. Cited in, Ahonsi, B. A 1988. "Deliberate falsification and census data in Nigeria." African Affairs 87, (349): 553-562.

Kolapo, Y and Faloseyi, M 2007, February 6. "Lagos and the fallacies in national census figures." Lagos, Nigeria: The Punch, p.3.

Kolapo, Y, Obasola, K, and Ibona, J 2007, February 6. "Lagos protests census results, heads for tribunal." Lagos, Nigeria: The Punch, p.2.

Macleod-Smith, A. M (1946): The collection of statistics as it affects the development programme. A Ten-Year Plan for Development and Welfare for Nigeria, 1946. Government Printer, Lagos. Appendix XXI, pp. | 30-I 3 |

Makinwa, P. K 1985. "Population Data: The Importance of Census, Sample Survey and Vital Registration System." Population Education Monograph, 15, Lagos: Nigerian Educational Research Council.

Morah, B. C, Adekunle, C. F and Adekunle, J. A I98I. "Evaluation of Past and Recommendations with Respect to Population Counts in Nigeria." In, $\mathrm{H}$. Chojaacka, P. Olusanya and F. Ojo (eds.) Population and Economic Development in Nigeria in the Nineteen Eighties. United Nations, TCD/SEM, 8I/2, New York, pp. I4-I6.

National Population Commission website, 2018 National Census To Gulp N222.9 Billion 
http://www.population.gov.ng/images/news_events/ Nigeria\%20Needs\%20N222bn\%20to\%20Condu ct\%202018\%20National\%20Census.pdf

Accessed I 7th January 2017

Nigeria (1970): Second National Development Plan, 1970-74. Lagos, Nigeria: Ministry of Information.

Nigeria (1975): Third National Development Plan, 1975-80. Lagos, Nigeria: Ministry of National Planning.

Obasanjo, $O$ 2006, March 21. "Census is indispensable to the nation's quest of sustainable development." The Guardian, p.9.

Obono, O. and Omoluabi E, 2014. "Technical and political aspects of the 2006 Nigerian population and housing census," Etude de la Population Africaine/African Population Studies 27, (2 Supp.): 249-262

Ogunlesi, T. O 1968. "Before and After a Population Census in Nigeria: a physician's experience." In, J.C. Caldwell and C. Okonjo (Eds.) The Population of tropical Africa. London: Longmans, pp. 79-82

Okafor, S, (198I): Indirect Rule: The Development of Central Legislative in Nigeria. Lagos: Nelson.

Okolo, A 1999. "The Nigerian Census: Problems and Prospects.” The American Statistician 53 (4): 32 I325.

Okonjo, C, 1968. "A Preliminary Medium Estimate of the 1962 mid-year Population of Nigeria." In, J.C. Caldwell and C. Okonjo (Eds.) The Population of tropical Africa. London: Longmans, pp. 79-82

Olusanya, P. O 1989a. "Population and Development Planning in Nigeria." In T. Tamuno, and Atanda J.A. (Eds.) Nigeria since Independence The First 25 years Government and Public Policy. Ibadan: Heinemann.

Olusanya, P. O 1989b. "Evolution and status of family planning in Nigeria. In, Developments in family planning policies and programmes in Africa." Proceedings of a Colloquium on the Impact of Family Planning in Sub-Saharan Africa: Current Issues and Prospects. Regional Institute for Population Studies, University of Ghana (Legon), 1989. pp 408-450.

Onyeka-Ben, V 2007, January 12. "It is tinted with political permutations." Lagos, Nigeria: The
Guardian, 28. In, Bamgbose, B. J 2009. "Falsification of population census data in a heterogeneous Nigerian state: The fourth republic example." African Journal of Political Science and International Relations 3, (8): 3 I I-3 I 9.

Orubuloye, I. O 1989. "Population Policy in Nigeria. In, Developments in family planning policies and programmes in Africa." Proceedings of a Colloquium on the Impact of Family Planning in Sub-Saharan Africa: Current Issues and Prospects. Regional Institute for Population Studies, University of Ghana (Legon), 1989. pp 45I-472

Shryock, H. S, and Siegel, J. S (1973): The Methods and Materials of Demography. Washington, DC: U.S. Department of Commerce, Bureau of the Census

The Economist 2000. "A survey of Nigeria. A tale of two giants. Why Indonesia has beaten Nigeria hands down." Jan 13th 2000. The Economist. http://www.economist.com/node/273185

Accessed January 20, 2017

The World Bank. World DataBank, World Development Indicators, Population, Nigeria. http://databank.worldbank.org/data/reports.aspx?s ource $=2 \&$ series $=$ SP.POP.TOTL\&country $=$ NGA Accessed online January 23, 2017

Tinubu, B. A 2007, February 6. "The falsification of Lagos Census figures being the test of a report by the Lagos State Government." Lagos, Nigeria: The Punch, p.3

Udo, R. K 1968. "Population and Politics in Nigeria." In, J.C. Caldwell and C. Okonjo (eds), The Population of tropical Africa. London: Longmans, p. 97.

United Nations 1967. Principles and Recommendations for the 1970 Population Censuses. Statistical Papers Series M, (44): I-3.

Population Reference Bureau, 2016 World Population Data Sheet, Population Reference Bureau, Washington DC.

Yesufu, "The Politics and Economics of Nigeria's Population Census," pp. I08-III. Cited in, Ahonsi, B. A 1988. "Deliberate falsification and census data in Nigeria." African Affairs 87, (349): 553-562. 